Goldschmidt 2021 Abstract

https://doi.org/10.7185/gold2021.5736
Kaapvaal 'continent' at around 3.5 Ga.

[1] Robin-Popieul et al., 2012, Journal of Petrology 53, 2191-

\section{The Paleoarchean Buffalo River komatiites: Evidence for progressive melting of a single large mantle plume beneath the growing Kaapvaal continent}

THENDO NETSHIDZIVHE ${ }^{1}$, SEBASTIAN TAPPE ${ }^{2}$, ALLAN WILSON ${ }^{3}$, AKIRA ISHIKAWA ${ }^{4,5}$ AND FANUS VILJOEN $^{2}$

${ }^{1}$ University Of Johannesburg

${ }^{2}$ University of Johannesburg

${ }^{3}$ University of the Witwatersrand

${ }^{4}$ Tokyo Institute of Technology

${ }^{5}$ Japan Agency for Marine Earth Science and Technology(JAMSTEC)

Presenting Author: thendon@uj.ac.za

Whole-rock geochemical data reveal three types of komatiites as part of the Paleoarchean Buffalo River Greenstone Belt at the southern margin of the Kaapvaal craton, South Africa. The three komatiite types occur within a single volcanic succession, which implies strong petrogenetic links between them. Spinifex textured lava flows are classified as Al-depleted komatiites, with subchondritic $\mathrm{Al}_{2} \mathrm{O}_{3} / \mathrm{TiO}_{2}$ ratios (5-12) and LREE enrichment over HREE $\left(\mathrm{Gd} / \mathrm{Yb}_{\mathrm{N}}=1-2\right)$. The second type comprises Alundepleted komatiites with chondritic $\mathrm{Al}_{2} \mathrm{O}_{3} / \mathrm{TiO}_{2}$ (17-24) and flat REE patterns $\left(\mathrm{Gd} / \mathrm{Yb}_{\mathrm{N}}=0.9-1.2\right)$. The third type comprises Al-enriched komatiites displaying suprachondritic $\mathrm{Al}_{2} \mathrm{O}_{3} / \mathrm{TiO}_{2}$ ratios $>25$, with a significant LREE depletion and HREE enrichment $\left(\mathrm{Gd} / \mathrm{Yb}_{\mathrm{N}}=0.2-0.6\right)$. The results show that both $\mathrm{Al}$ depleted and Al-undepleted komatiites are geochemically similar to archetypal komatiites from the $3.5 \mathrm{Ga}$ Komati and $3.3 \mathrm{Ga}$ Weltevreden formations of the Barberton Greenstone Belt. In contrast, the Al-enriched komatiites resemble the $3.3 \mathrm{Ga}$ Commondale komatiites on the SE Kaapvaal craton. To explain the co-occurrence of three discrete komatiite types within a single volcanic succession, we suggest that each major komatiite magmatic pulse originated from the same dynamically upwelling mantle source, from which melt was extracted at different P-T conditions, with variable plume-lithosphere interactions. Preliminary whole-rock ${ }^{187} \mathrm{Os} /{ }^{188} \mathrm{Os}$ data show initial values as low as 0.107 for the Al-depleted komatiites, pointing to an ultimate origin from primitive mantle during the Paleoarchean. The highly siderophile element patterns of the Al-depleted komatiites are similar to those of the Al-depleted komatiites from the Barberton type locality, for which an origin from the deepest upper mantle with high melt retention in an upwelling 'plume' source was suggested [1]. Similar to Barberton, progressive melting of such an upwelling mantle source, to the point of garnet/majorite exhaustion, may explain the Al-undepleted and Al-enriched komatiites of the Buffalo River Greenstone Belt. The first evidence from Buffalo River suggests, however, that co-occurrence of all three major komatiite types is linked to deep critical melting of a single large mantle plume that may have been intimately associated with the formation and growth of the 